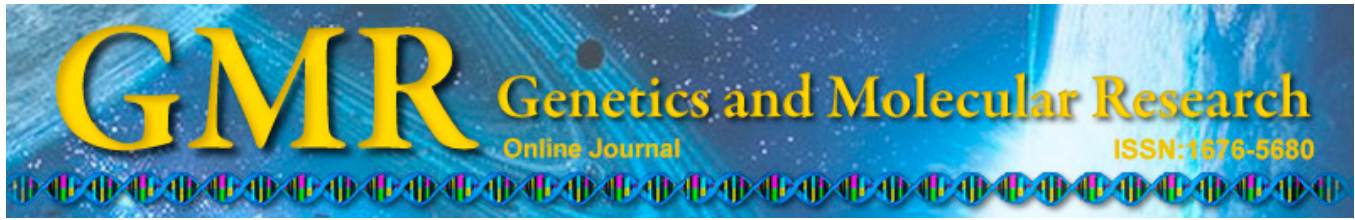

\title{
Protective effects of ascorbic acid and vitamin $E$ on antioxidant enzyme activity of freeze-thawed semen of Qinchuan bulls
}

\author{
X.L. Zhao ${ }^{1,2}$, Y.K. Li ${ }^{1}$, S.J. Cao ${ }^{2}$, J.H. Hu ${ }^{1}$, W.H. Wang ${ }^{2}$, \\ R.J. Hao ${ }^{1}$, L.S. Gui ${ }^{1}$ and L.S. Zan ${ }^{1}$ \\ ${ }^{1}$ College of Animal Science and Technology, Northwest A\&F University, \\ Yangling, Shaanxi, China \\ ${ }^{2}$ Weinan Vocational \& Technical College, Weinan, Shaanxi, China \\ Corresponding author: L.S. Zan \\ E-mail: zanlinsen@163.com
}

Genet. Mol. Res. 14 (1): 2572-2581 (2015)

Received March 10, 2014

Accepted July 23, 2014

Published March 30, 2015

DOI http://dx.doi.org/10.4238/2015.March.30.16

\begin{abstract}
The aim of this study was to determine the protective effects of the combination of ascorbic acid (Vc) and vitamin E (VE) on antioxidant enzyme activity, sperm motility, viability, and acrosome integrity of Qinchuan bulls after freeze-thaw. In this study, we determined the effects of $\mathrm{Vc}$ and $\mathrm{VE}$ on the activity of the antioxidant enzyme defense system comprising glutathione peroxidase (GSH-Px), glutathione reductase (GR), catalase (CAT), and superoxide dismutase (SOD). The combination of Vc and VE had protective effects on sperm motility and viability. With respect to acrosome integrity and the activity of GR and SOD, differences were observed between the experimental groups with added Vc $(7 \mathrm{mg} / \mathrm{mL})$ and VE $(0.12 \mathrm{IU} / \mathrm{mL})$ and the control group. The activity of GSH-Px in the experimental group $(1400 \mathrm{IU} / \mathrm{mL}$ $\mathrm{Vc}$ and $0.12 \mathrm{IU} / \mathrm{mL} \mathrm{VE})$ was not different $(\mathrm{P}>0.05)$ compared with that in the control group, while the activity of CAT showed a significant difference between the 2 groups $(\mathrm{P}<0.05)$. Therefore, we inferred that
\end{abstract}


the combination of $\mathrm{Vc}(1400 \mathrm{IU} / \mathrm{mL})$ and $\mathrm{VE}(0.12 \mathrm{IU} / \mathrm{mL})$ protected the sperm quality in the freeze-thaw process.

Key words: Qinchuan bull; Glutathione peroxidase; Catalase; Superoxide dismutase; Glutathione reductase

\section{INTRODUCTION}

The presence of reactive oxygen species (ROS) has a noxious effect on sperm survival and fertilization ( $\mathrm{Hu}$ et al., 2010; Maia et al., 2010). The production of ROS is a normal physiological event in every organ including the testis, but the over-production of ROS can cause structural damage to sperm membranes, which results in the formation of cytotoxic secondary products such as malondialdehyde (Sharma and Agarwal, 1996; De Lamirande et al., 1997). Additionally, the presence of leukocytes in seminal plasma was responsible for the generation of ROS in human semen (Aitken and West, 1990). In bovine, ROS was generated primarily by dead spermatozoa via an aromatic amino acid oxidasecatalyzed reaction (Upreti et al., 1998). Therefore, decreasing the ROS content in seminal plasma is important. Antioxidants have an important role in maintaining the motility and the genetic integrity of sperm cells against oxidative damage (Hughes et al., 1998). Superoxide dismutase (SOD), glutathione reductase (GR), catalase (CAT), and glutathione peroxidase (GSH-Px) are natural antioxidant enzymes that can eliminate ROS. These antioxidants exerted a protective effect on the plasma membrane in cryopreserved bovine spermatozoa, preserving both metabolic activity and cellular viability (Beconi et al., 1993; O'Flaherty et al., 1997). However, the activity of these natural antioxidant enzymes was comparatively weak, and semen was very susceptible to oxidative stress (Jones and Mann, 1977).

To inhibit the production of ROS, antioxidants are added in semen diluters or in livestock feed. Some reports indicated that the addition of ascorbic acid (Vc) and vitamin E (VE) to animal feeds could reduce the production of ROS and raise the quality of sperm (Fraga et al., 1991; Akiyama, 1999; Li et al., 2010). Massaeli et al. (1999) reported that Vc and VE could inhibit the lipid peroxidation and showed that VE was better at reducing ROS than other antioxidants.

VE, a chain-breaking antioxidant, is a primary component of the antioxidant system. It intercepts peroxyl and alkoxyl radicals, which were generated during the conversion of lipid hydroperoxides that have an important role in the peroxidative chain reaction (Aitken and Clarkson, 1988; Thérond et al., 1996). Vc is another primary component of the antioxidant system. Vc can improve sperm viability, decrease the percentage of abnormality, and increase the activity of sperm motility (Dawson et al., 1992; Branco et al., 2010; Paudel et al., 2010).

Although the effects of Vc and VE on antioxidant enzyme activity were previously reported, the effects of their combination on antioxidant enzyme activity and the sperm activity of Qinchuan bulls after freeze-thawing have not been evaluated.

As an elite yellow cattle breed, Qinchuan cattle have a long history of feeding and breeding in China. Qinchuan cattle were mainly used as draught animals throughout their long history. In the long history of selection and breeding, Qinchuan cattle experienced draft type selection, dual type of draft, and beef purpose selection. Although artificial fertilization has 
been used in cows, the protection of the antioxidant activity in Qinchuan cattle freeze-thawed seminal plasma was not reported.

In this study, we determined the effect of the combination of Vc and VE on the activity of the antioxidant enzyme defense system, which contained SOD, GR, GSH-Px, and CAT, in freeze-thawed semen from Qinchuan bulls. In addition, the motility and viability of sperm in different combinations of Vc and VE were evaluated. Further, we determined the SOD, GR, GSH-Px, and CAT index of Qinchuan bull freeze-thawed semen antioxidant enzyme defense system after treatment with different combinations of $\mathrm{Vc}$ and VE.

\section{MATERIAL AND METHODS}

\section{Diluent preparation}

In this study, the extender contained $2.9 \%$ sodium citrate dehydrate, $20 \%$ egg yolk, $5.5 \%$ glycerine, $5 \%$ sucrose, $1000 \mathrm{U} / \mathrm{mL}$ gentamicin, $200 \mu \mathrm{g} / \mathrm{mL}$ spectinomycin, $1000 \mathrm{U} / \mathrm{mL}$ cillimycin, and distilled water to a volume of $100 \mathrm{~mL}$. Different concentrations of Vc (Sigma Chemical, Co., Ltd., USA) and VE (Sigma Chemical, Co., Ltd.) were added to diluents. The content of Vc and VE was defined according to our study (not reported). The cooling diluents were prepared by adding Vc $(1200,1400$, and $1600 \mathrm{IU} / \mathrm{mL})$ and VE $(0.09,0.11$, and $0.12 \mathrm{IU} /$ $\mathrm{mL}$ ) in different combinations in basic diluents.

\section{Semen collection}

The semen was collected using an artificial vagina from 8 mature Qinchuan bulls twice per week. The bulls, which ranged from 2 to 6 years of age, belonged to the Improvement Station of Domestic Animal in Shaanxi, China, and were kept under uniform feeding and handling conditions during the entire study. The semen samples were assessed for volume, sperm concentration, percentage of motile spermatozoa (the sperm of straight-line movement), and quality of movements. Only samples with a minimum of $70 \%$ motile and $80 \%$ morphologically normal spermatozoa were used in this study.

\section{Semen freezing}

The semen-freezing process in this study was modified from the protocol reported in a recent study (Stradaioli et al., 2007). Diluted semen was balanced at room temperature for $1 \mathrm{~h}$, loaded into $0.25-\mathrm{mL}$ plastic straws, and placed on freezing trays. Semen was frozen by transferring these trays to a programmable freezing device (Mini Digitcool, IMV, France) at $4^{\circ} \mathrm{C}$. Straws were frozen to $-5^{\circ} \mathrm{C}$ at a rate of $-3^{\circ} \mathrm{C} / \mathrm{min}$, from -5 to $-40^{\circ} \mathrm{C}$ at a rate of $-40^{\circ} \mathrm{C} / \mathrm{min}$, and from -40 to $-120^{\circ} \mathrm{C}$ at a rate of $-10^{\circ} \mathrm{C} / \mathrm{min}$; straws were subsequently plunged into liquid nitrogen.

\section{Thawing semen}

The sperm samples were taken out of the liquid nitrogen and thawed at $37.5^{\circ} \mathrm{C}$ for 30 $\mathrm{s}$ after storage for 30 days. 


\section{Sperm motility and viability}

The characteristics of sperm motion were assessed with the WLJY-9000, a computer-aided sperm analysis system (WeiLi Software Co., Ltd., Beijing, China). For each extender, 3 straws were thawed separately by immersion in a water bath at $37^{\circ} \mathrm{C}$ for 45 s. The thawed semen samples were immediately transferred to plastic tubes of $1 \mathrm{~mL}$ and incubated at $37^{\circ} \mathrm{C}$ for $10 \mathrm{~min}$. Five microliters of each straw was examined, and 6 fields were randomly chosen. The median values of sperm motility ( $\%$ of motile spermatozoa), the straight-line velocity (VSL, $\mu \mathrm{m} / \mathrm{s}$ ), the curvilinear velocity (VCL, $\mu \mathrm{m} / \mathrm{s}$ ), and velocity of the average path (VAP, $\mu \mathrm{m} / \mathrm{s}$ ) were obtained from the video recording. The linearity index [LIN $=(\mathrm{VSL} / \mathrm{VCL}) \times 100]$ and mean coefficient $[\mathrm{STR}=(\mathrm{VSL} / \mathrm{VAP}) \times 100]$ were analyzed.

\section{Acrosome integrity}

The acrosome integrity was determined according to Zhang (2004). Three hundred spermatozoa were evaluated to determine acrosome integrity with the combined techniques of Giemsa stain and statistical analysis.

\section{Enzymatic activity determination}

The supernatant that was used in this study was obtained by spinning semen of freezethawed samples at $3000 \mathrm{~g}$ for $10 \mathrm{~min}$ at $4^{\circ} \mathrm{C}$.

\section{GSH-Px}

The GSH-Px activity was measured by a GSH-Px kit (Nanjing Jiancheng, China) according to kit directions. The GSH-Px activity was expressed as U/L.

\section{Glutathione reductase (GR)}

The plasma GR activity was determined according to Marti et al. (2007). The reaction mixture contained sodium phosphate buffer, $0.6 \mathrm{mM}$ oxidized glutathione, $0.5 \mathrm{mM}$ ethylenediaminetetraacetic acid (EDTA), $85 \mu \mathrm{M}$ NADPH $+\mathrm{H}^{+}$. One unit of GR activity will cause the oxidation of $1.0 \mu \mathrm{mol} \mathrm{NADPH} / \mathrm{min}$ at $25^{\circ} \mathrm{C}$ and $\mathrm{pH} 7.5$. The GR activity was expressed as U/L.

\section{CAT}

The plasma CAT activity was measured according to Góth (1991). Plasma samples $(0.3 \mathrm{~mL})$ were incubated in $1.7 \mathrm{~mL}$ substrate $(65 \mu \mathrm{M}$ hydrogen peroxide in $50 \mathrm{mM}$ phosphate buffer, $\mathrm{pH} 7.0$ ) at $37.5^{\circ} \mathrm{C}$ for $60 \mathrm{~s}$. The enzymatic reaction was terminated with $1.0 \mathrm{~mL} 32.4$ $\mathrm{mM}$ ammonium molybdate. Hydrogen peroxide was measured at $405 \mathrm{~nm}$ against a blank containing all the components except the enzyme on a spectrophotometer. The CAT activity was expressed as $\mathrm{U} / \mathrm{mL}$. 


\section{SOD}

The plasma SOD activity was measured as previously described by Flohé and Otting (1984). Each sample was diluted 1:5 using phosphate-buffered sodium $(0.8 \mathrm{~g} / \mathrm{dL} \mathrm{NaCl}, 0.02$ $\mathrm{g} / \mathrm{dL} \mathrm{KCl}, 0.156 \mathrm{~g} / \mathrm{dL} \mathrm{Na}_{2} \mathrm{HPO}_{4}-\mathrm{H}_{2} \mathrm{O}$, and $0.02 \mathrm{~g} / \mathrm{dL} \mathrm{KH}_{2} \mathrm{PO}_{4}$ ). Assay solution containing 50 $\mathrm{mM}$ sodium-carbonate buffer, $\mathrm{pH} 10,0.1 \mathrm{mM}$ xanthine, $0.025 \mathrm{mM}$ nitro blue tetrazolium, 0.1 mM EDTA, and xanthine oxidase was mixed with the sample in a small cuvette. One unit of SOD activity was defined as the amount of enzyme required to inhibit nitro blue tetrazolium. The SOD in plasma was measured at $560 \mathrm{~nm}$ by the degree of inhibition of this reaction on a spectrophotometer and expressed as $\mathrm{U} / \mathrm{mL}$.

\section{Statistical analysis}

Results are reported as means \pm standard error of the mean. Means were compared by analysis of variance tests and least significant difference to determine whether there were any significant differences between samples using SPSS 16.0. $\mathrm{P}<0.05$ was considered to be statistically different. $\mathrm{P}<0.01$ was considered to be significantly different.

\section{RESULTS}

\section{Sperm motility and movement characteristics}

The effects of the Vc and VE supplementation in the extender on motion characteristics of cryopreserved sperm are shown in Tables 1 and 2. The sperm motility and motion characteristics were improved with the presence of $\mathrm{Vc}$ and $\mathrm{VE}$ in the extender compared to the control group. The group with $1400 \mathrm{IU} / \mathrm{mL} \mathrm{Vc}$ and $0.11 \mathrm{IU} / \mathrm{mL}$ VE and that with $1400 \mathrm{IU} / \mathrm{mL}$ $\mathrm{Vc}$ and $0.12 \mathrm{IU} / \mathrm{mL} \mathrm{VE}$ were different from the control group $(\mathrm{P}<0.05)$. This result certified that the addition of $1400 \mathrm{IU} / \mathrm{mL} \mathrm{Vc}$ and $0.12 \mathrm{IU} / \mathrm{mL} \mathrm{VE}$ had the best effect on the protection of the sperm motility after freeze-thaw.

$\mathrm{Vc}$ and VE in semen diluter could protect the sperm viability after freeze-thaw. Sperm viability was significantly higher in the group with $1400 \mathrm{IU} / \mathrm{mL} \mathrm{Vc}$ and $0.12 \mathrm{IU} / \mathrm{mL}$ VE than in the control group. The other groups showed no difference in sperm viability compared with the control group. This result indicated that $1400 \mathrm{IU} / \mathrm{mL} \mathrm{Vc}$ and $0.12 \mathrm{IU} / \mathrm{mL} \mathrm{VE}$ had the best protection of sperm viability after freeze-thaw.

The sperm acrosome integrity was presented in Table 1. The database showed that added Vc and VE could protect the sperm acrosome after freeze-thaw. Results indicated that the sperm acrosome integrity was significantly higher $(\mathrm{P}<0.05)$ in the group with $1400 \mathrm{IU} /$ $\mathrm{mL} \mathrm{Vc}$ and $0.12 \mathrm{IU} / \mathrm{mL}$ VE than in the control group. The sperm acrosome integrity was the highest when $1400 \mathrm{IU} / \mathrm{mL} \mathrm{Vc}$ and $0.12 \mathrm{IU} / \mathrm{mL}$ VE were added. This result suggested that $1400 \mathrm{IU} / \mathrm{mL} \mathrm{Vc}$ and $0.12 \mathrm{IU} / \mathrm{mL} \mathrm{VE}$ had the best effect on the protection of sperm acrosome integrity through the freeze-thaw process.

Sperm motion characteristics are shown in Table 2. The motility, VSL, VCL, STR, and VAP values in the extender supplemented with $1400 \mathrm{IU} / \mathrm{mL} \mathrm{Vc}$ and $0.12 \mathrm{IU} / \mathrm{mL}$ VE were significantly higher than those of other concentrations $(\mathrm{P}<0.05)$, whereas differences in the LIN and VAP values were not significant $(\mathrm{P}>0.05)$. 
Table 1. Computer-aided sperm analysis (CASA)-obtained mean values of motility parameters from freezethawed bovine semen samples in the presence and the absence of ascorbic acid (Vc) and vitamin E (VE).

\begin{tabular}{|c|c|c|c|}
\hline Group & Sperm motility (\%) & Sperm viability (\%) & Sperm acrosome integrity (\%) \\
\hline Control & $54.58 \pm 2.76^{\mathrm{a}}$ & $73.23 \pm 2.65^{\mathrm{a}}$ & $71.81 \pm 1.36^{\mathrm{a}}$ \\
\hline C6E7 (1200 IU/mL Vc + $0.11 \mathrm{IU} / \mathrm{mL}$ VE) & $60.23 \pm 3.3 \mathrm{a}^{\mathrm{b}}$ & $75.07 \pm 1.50^{\mathrm{ab}}$ & $74.43 \pm 3.37^{\mathrm{a}}$ \\
\hline C6E8 $(1200 \mathrm{IU} / \mathrm{mL} \mathrm{Vc}+0.12 \mathrm{IU} / \mathrm{mL}$ VE) & $59.07 \pm 2.93^{\mathrm{ab}}$ & $77.03 \pm 2.93^{\mathrm{ab}}$ & $75.11 \pm 3.20^{\mathrm{a}}$ \\
\hline C7E6 $(1400 \mathrm{IU} / \mathrm{mL} \mathrm{Vc}+0.09 \mathrm{IU} / \mathrm{mL} \mathrm{VE})$ & $60.20 \pm 4.88^{\mathrm{ab}}$ & $77.73 \pm 3.54^{\mathrm{ab}}$ & $77.45 \pm 1.49^{\mathrm{a}}$ \\
\hline C7E7 $(1400 \mathrm{IU} / \mathrm{mL} \mathrm{Vc}+0.11 \mathrm{IU} / \mathrm{mL}$ VE) & $60.75 \pm 3.87^{\mathrm{b}}$ & $78.10 \pm 2.34^{\mathrm{ab}}$ & $79.21 \pm 2.55^{\mathrm{b}}$ \\
\hline C7E8 $(1400 \mathrm{IU} / \mathrm{mL} \mathrm{Vc}+0.12 \mathrm{IU} / \mathrm{mL} \mathrm{VE})$ & $62.30 \pm 4.67^{\mathrm{b}}$ & $78.93 \pm 0.74^{\mathrm{b}}$ & $80.18 \pm 2.72^{\mathrm{b}}$ \\
\hline C8E6 $1600 \mathrm{IU} / \mathrm{mL} \mathrm{Vc}+0.09 \mathrm{IU} / \mathrm{mL} \mathrm{VE)}$ & $60.53 \pm 3.17^{\mathrm{ab}}$ & $76.57 \pm 3.45^{\mathrm{ab}}$ & $72.20 \pm 1.14^{\mathrm{a}}$ \\
\hline C8E7 (1600 IU $/ \mathrm{mL} \mathrm{Vc}+0.11 \mathrm{IU} / \mathrm{mL}$ VE) & $58.68 \pm 3.48^{\mathrm{ab}}$ & $75.77 \pm 3.98^{\mathrm{ab}}$ & $69.32 \pm 2.30^{\mathrm{b}}$ \\
\hline
\end{tabular}

Values are means \pm SE of motility parameters from the CASA data set of freeze-thawed bovine spermatozoa with different treatments. Values in the same column with different letters are significantly different $(\mathrm{P}<0.05)$.

Table 2. CASA-obtained mean values of motility parameters from freeze-thawed bovine semen samples in the presence and the absence of $\mathrm{Vc}$ and VE.

\begin{tabular}{|c|c|c|c|c|c|}
\hline Group & $\operatorname{VSL}(\mu \mathrm{m} / \mathrm{s})$ & $\operatorname{VCL}(\mu \mathrm{m} / \mathrm{s})$ & LIN (\%) & STR $(\%)$ & $\operatorname{VAP}(\mu \mathrm{m} / \mathrm{s})$ \\
\hline Control & $42.75 \pm 2.41^{\mathrm{ab}}$ & $20.97 \pm 2.48^{\mathrm{ab}}$ & $25.97 \pm 2.90^{\mathrm{b}}$ & $55.01 \pm 3.17^{\mathrm{a}}$ & $70.98 \pm 1.97^{\mathrm{abc}}$ \\
\hline C6E7 (1200IU/mL Vc + $0.11 \mathrm{IU} / \mathrm{mL}$ VE) & $45.11 \pm 2.25^{\mathrm{c}}$ & $25.02 \pm 2.41^{\mathrm{c}}$ & $27.30 \pm 2.31^{\mathrm{bc}}$ & $60.01 \pm 2.24^{\mathrm{b}}$ & $77.74 \pm 3.65^{\mathrm{d}}$ \\
\hline C6E8 (1200 IU/mL Vc + $0.12 \mathrm{IU} / \mathrm{mL}$ VE) & $58.87 \pm 1.33 b^{c}$ & $24.23 \pm 2.71^{\mathrm{bc}}$ & $28.69 \pm 2.38^{\mathrm{bc}}$ & $65.54 \pm 3.19^{\mathrm{bc}}$ & $77.26 \pm 2.31^{\mathrm{d}}$ \\
\hline C7E6 (1400 IU/mL Vc + $0.09 \mathrm{IU} / \mathrm{mL} \mathrm{VE})$ & $57.88 \pm 2.34^{\mathrm{c}}$ & $25.89 \pm 2.09^{\mathrm{c}}$ & $30.61 \pm 3.78^{c}$ & $66.10 \pm 4.23^{\mathrm{c}}$ & $74.86 \pm 1.76^{\mathrm{cd}}$ \\
\hline C7E7 $(1400 \mathrm{IU} / \mathrm{mL} \mathrm{Vc}+0.11 \mathrm{IU} / \mathrm{mL} \mathrm{VE})$ & $60.13 \pm 2.46^{\mathrm{d}}$ & $30.28 \pm 2.86^{\mathrm{d}}$ & $36.38 \pm 3.28^{\mathrm{d}}$ & $77.52 \pm 2.73^{\mathrm{cd}}$ & $77.75 \pm 3.04^{\mathrm{d}}$ \\
\hline C7E8 (1400 IU/mL Vc + 0.12 IU/mL VE) & $51.71 \pm 2.24^{\mathrm{d}}$ & $31.92 \pm 2.04^{\mathrm{d}}$ & $29.81 \pm 3.32^{\mathrm{bc}}$ & $67.10 \pm 4.47^{\mathrm{d}}$ & $73.34 \pm 1.82^{\mathrm{bcd}}$ \\
\hline C8E6 (1600 IU/mL Vc + $0.09 \mathrm{IU} / \mathrm{mL}$ VE) & $48.11 \pm 2.45^{\mathrm{bc}}$ & $22.94 \pm 1.10^{\mathrm{bc}}$ & $28.12 \pm 1.40^{\mathrm{bc}}$ & $62.11 \pm 2.59^{\mathrm{bc}}$ & $69.91 \pm 2.58^{\mathrm{ab}}$ \\
\hline C8E7 (1600IU/mL Vc + 0.11 IU/mL VE) & $40.36 \pm 2.13^{\mathrm{a}}$ & $19.01 \pm 3.14^{\mathrm{a}}$ & $21.15 \pm 2.26^{\mathrm{a}}$ & $58.12 \pm 2.63^{\mathrm{bc}}$ & $67.83 \pm 3.91^{\mathrm{a}}$ \\
\hline
\end{tabular}

Values are means \pm SE of freeze-thawed bovine spermatozoa. Values in the same column with different letters are significantly different $(\mathrm{P}<0.05)$. VSL, straight-line velocity; VCL, curvilinear velocity; LIN, linearity index (LIN = VSL / VCL x 100); STR, mean coefficient (STR = VSL / VAP x 100); and VAP, velocity of the average path.

\section{Effects of Ve and VE on antioxidant enzyme activity}

The SOD activity in freeze-thawed semen is presented in Table 3 . There was a significant difference $(\mathrm{P}<0.05)$ in the SOD activity of the group with $1400 \mathrm{IU} / \mathrm{mL}$ Vc and $0.12 \mathrm{IU} /$ $\mathrm{mL} V E$ compared with that in the control group. There were nonsignificant differences $(\mathrm{P}>$ 0.05 ) between other groups and the control group, but the values were lower than those with $1400 \mathrm{IU} / \mathrm{mL} \mathrm{Vc}$ and $0.12 \mathrm{IU} / \mathrm{mL}$ VE. We could conclude that $1400 \mathrm{IU} / \mathrm{mL} \mathrm{Vc}$ and $0.12 \mathrm{IU} / \mathrm{mL}$ VE had more protective effects on the SOD activity than other groups.

The CAT activity values in freeze-thawed sperm are presented in Table 3. There was a significant difference in the CAT activity in the group with $1400 \mathrm{IU} / \mathrm{mL} \mathrm{Vc}$ and $0.12 \mathrm{IU} / \mathrm{mL}$ VE compared with the control group. Other groups also had significant differences compared with the control group, but the values were lower than with $1400 \mathrm{IU} / \mathrm{mL} \mathrm{Vc}$ and $0.12 \mathrm{IU} / \mathrm{mL}$ VE. This analysis indicated that $1400 \mathrm{IU} / \mathrm{mL} \mathrm{Vc}$ and $0.12 \mathrm{IU} / \mathrm{mL}$ VE had the best protection of CAT activity.

The GSH-Px activity values in freeze-thawed semen are presented in Table 3. Although the GSH-Px activity was higher in the group with $1400 \mathrm{IU} / \mathrm{mL} \mathrm{Vc}$ and $0.12 \mathrm{IU} / \mathrm{mL} \mathrm{VE}$, there was no significant difference between it and the control group $(\mathrm{P}>0.05)$.

The GR activity values of freeze-thawed semen are presented in Table 3. The group with $1400 \mathrm{IU} / \mathrm{mL} \mathrm{Vc}$ and $0.12 \mathrm{IU} / \mathrm{mL}$ VE had a GR activity that was significantly different compared with that of the control group, and the value was higher than that of other groups. 
This suggested that the combination of $1400 \mathrm{IU} / \mathrm{mL} \mathrm{Vc}$ and $0.12 \mathrm{IU} / \mathrm{mL}$ VE had the best protection of the GR activity.

Table 3. Total superoxide dismutase (SOD), catalase (CAT), glutathione peroxidase (GSH-Px), and glutathione reductase (GR) levels in freeze-thawed bovine semen in the presence and the absence of Vc and VE.

\begin{tabular}{|c|c|c|c|c|}
\hline Group & $\mathrm{SOD}(\mathrm{U} / \mathrm{mL})$ & CAT $(\mathrm{U} / \mathrm{mL})$ & GSH-Px (U/L) & GR (U/L) \\
\hline Control & $1.9 \pm 0.11^{\mathrm{a}}$ & $1.16 \pm 0.82^{\mathrm{a}}$ & $117.33 \pm 1.96^{\text {cd }}$ & $87.63 \pm 1.06^{\mathrm{a}}$ \\
\hline C6E7 $(1200 \mathrm{IU} / \mathrm{mL} \mathrm{Vc}+0.11 \mathrm{IU} / \mathrm{mL} \mathrm{VE})$ & $2.33 \pm 0.21^{b}$ & $1.25 \pm 0.056^{\mathrm{a}}$ & $102.77 \pm 1.62^{\mathrm{a}}$ & $100.83 \pm 1.10^{\mathrm{b}}$ \\
\hline C6E8 (1200 IU/mL Vc + $0.12 \mathrm{IU} / \mathrm{mL} \mathrm{VE})$ & $2.57 \pm 0.21^{b}$ & $1.55 \pm 0.13^{\mathrm{bc}}$ & $113.33 \pm 2.08^{\mathrm{bc}}$ & $101.83 \pm 1.33^{\mathrm{b}}$ \\
\hline C7E6 $(1400 \mathrm{IU} / \mathrm{mL} \mathrm{Vc}+0.09 \mathrm{IU} / \mathrm{mL}$ VE $)$ & $2.7 \pm 0.26^{\mathrm{bc}}$ & $1.7 \pm 0.081^{\mathrm{de}}$ & $114.13 \pm 3.09^{\mathrm{bc}}$ & $108.87 \pm 2.83^{\mathrm{c}}$ \\
\hline C7E7 $(1400 \mathrm{IU} / \mathrm{mL} \mathrm{Vc}+0.11 \mathrm{IU} / \mathrm{mL} \mathrm{VE})$ & $2.47 \pm 0.32^{b}$ & $1.78 \pm 0.13^{\mathrm{e}}$ & $114.29 \pm 2.88^{\mathrm{d}}$ & $121.50 \pm 3.01^{\mathrm{d}}$ \\
\hline C7E8 $(1400 \mathrm{IU} / \mathrm{mL} \mathrm{Vc}+0.12 \mathrm{IU} / \mathrm{mL}$ VE) & $3.07 \pm 0.21^{\mathrm{c}}$ & $1.88 \pm 0.05^{\mathrm{f}}$ & $118.87 \pm 2.69^{\mathrm{d}}$ & $126.83 \pm 2.7^{\mathrm{e}}$ \\
\hline C8E6 $1600 \mathrm{IU} / \mathrm{mL}$ Vc $+0.09 \mathrm{IU} / \mathrm{mL}$ VE) & $2.97 \pm 0.21^{\mathrm{c}}$ & $1.63 \pm 0.10^{\mathrm{de}}$ & $104.29 \pm 2.99^{\mathrm{bc}}$ & $109.6 \pm 3.25^{\mathrm{b}}$ \\
\hline C8E7 (1600 IU/mL Vc + $0.11 \mathrm{IU} / \mathrm{mL} \mathrm{VE})$ & $2.33 \pm 0.15^{b}$ & $1.45 \pm 0.056^{\mathrm{b}}$ & $105.1 \pm 2.03^{\mathrm{bc}}$ & $103.27 \pm 2.17^{\mathrm{a}}$ \\
\hline
\end{tabular}

Values are means \pm SE of freeze-thawed bovine spermatozoa. Values in the same column with different letters are significantly different $(\mathrm{P}<0.05)$.

\section{DISCUSSION}

In this study, the addition of Vc and VE to Qinchuan cattle semen extender could improve sperm quality and the activity of antioxidant enzymes (SOD, CAT, and GR) in semen after freeze-thaw.

\section{Effects of $V E$ and $V c$ on the quality of semen}

$\mathrm{VE}$ and $\mathrm{Vc}$ are well-known antioxidants that play a critical role in protecting sperm motility and viability. The supplementation of VE and Vc could improve oxidative stress-related testicular impairments in animal tissues (Askari et al., 1994; Ghosh et al., 2002; Marchlewicz et al., 2007; Acharya et al., 2008), and the sperm quality in smokers and male infertile patients could also be improved (Dawson et al., 1992). Jones and Mann (1977) reported that Vc was an effective radical scavenger that could reduce the content of free radicals. Adding $\mathrm{Vc}$ to seminal plasma could maintain the sperm cell integrity and effectively protect the sperm membrane. VE could enhance immunity by maintaining the functional and structural integrity of immune cells (Chew, 1995), and adding VE to Ovis aries semen diluter could improve the sperm motility after freeze-thaw (Richardson, 1976; Zhao and Wang, 1999). The addition of 5-10 mg/mL Vc in goat semen diluter could inhibit the metabolism of the sperm, which could extend the life of sperm (Sönmez and Demirci, 2004).

This study demonstrated that the combination of Vc and VE could improve the sperm motility and viability. From Table 1, we can conclude that there was a significant difference between the control group and the $1400 \mathrm{IU} / \mathrm{mL} \mathrm{Vc} 1400$ and $0.12 \mathrm{IU} / \mathrm{mL}$ VE experimental group. This study indicated that the addition of $\mathrm{Vc}$ and $\mathrm{VE}$ to semen extender had a beneficial effect on the spermatozoa activity. The reason for this benefit may be the result of the interaction between Vc and VE. Some experimental groups indicated that there was no difference compared with the control group, possibly because the osmotic pressure of the sperm diluter was too high, resulting in damage to the spermatozoa. 


\section{Effects of $\mathrm{VE}$ and $\mathrm{Vc}$ on the acrosome intact rate of spermatozoa}

The ability of spermatozoa to fertilize has very important relationships with semen appearance and acrosome integration. The normal semen acrosome and acrosome reaction were essential conditions for sperm-egg fusion. The spermatozoa plasma membrane and acrosome integration would be damaged in the freeze-thaw process. The damage to the structure of sperm cells decreases the fertilizability of freeze-thawed semen (Zhang, 2004). In this study, when $1400 \mathrm{IU} / \mathrm{mL}$ Vc and $0.12 \mathrm{IU} / \mathrm{mL}$ VE were added, the intact acrosome rate was significantly higher than that of the control group. The reason for this may be that the addition of $\mathrm{Vc}$ and VE to the diluter could reinforce the antioxidation of spermatozoa and reduce the detachment of sperm acrosomes.

\section{Effects of VE and Vc on the antioxidant enzyme activity}

It is well known that normal sperm count and other variables that are measured in routine semen analysis do not ensure a good fertility rate; the activity of antioxidant enzymes in human seminal plasma has been related to low fertility (Iwasaki and Gagnon, 1992; Huszar and Vigue, 1994; Sharma and Agarwal, 1996). Enzymatic activity of antioxidant enzymes is very important. When the enzymatic activity of antioxidant enzymes is low, ROS levels are relatively high, and an excess of ROS production rate could lead to infertility (Armstrong et al., 1999; Pasqualotto et al., 2001). The larger amount of ROS would initiate peroxidative lipid damage and inhibit sperm motility through the depletion of ATP, which is independent of oxidative phosphorylation (Armstrong et al., 1999).

Vc and VE, added separately to semen diluent, could improve the antioxidant enzymatic activity (Ball et al., 2001; Foote et al., 2002). This study proved that the combination of Vc and VE could also improve the activity. From Table 3, when the combination of 1400 $\mathrm{IU} / \mathrm{mL} \mathrm{Vc}$ and $0.12 \mathrm{IU} / \mathrm{mL}$ VE was added, the CAT value in seminal plasma was significantly higher $(\mathrm{P}<0.01)$, but the protecting effect on GSH-Px activity was not significant compared with that of the control group. The addition of Vc and VE to semen diluter could also improve the activity of antioxidant enzymes. The reason for this might be that VE and Vc, as antioxidants, inhibited the reduction of ROS, resisted damage from ROS in seminal plasma, or protected the antioxidant enzymatic activity during the freeze-thaw process.

\section{CONCLUSIONS}

The results obtained in this study showed that the addition of Vc and VE to semen extender could improve the Qinchuan bull spermatozoa motility and viability after freeze-thaw. This study also showed that the addition of $1400 \mathrm{IU} / \mathrm{mL} \mathrm{Vc}$ and $0.12 \mathrm{IU} / \mathrm{mL}$ VE had the best effect on sperm motility, viability, and acrosome intact rate, and it could elevate the activity of the antioxidant enzymes in freeze-thawed semen.

\section{ACKNOWLEDGMENTS}

Research supported by the National Twelfth "Five Year" Science and Technology Support Project (\#2011BAD28B04-03), the China National “863" Program (\#2011AA100307), the GMO New Varieties Major Project (\#2011ZX08007-002), and the National Beef and Yak Industrial Technology System (\#CARS-38). 


\section{REFERENCES}

Acharya UR, Mishra M, Patro J and Panda MK (2008). Effect of vitamins C and E on spermatogenesis in mice exposed to cadmium. Reprod. Toxicol. 25: 84-88.

Aitken RJ and Clarkson JS (1988). Significance of reactive oxygen species and antioxidants in defining the efficacy of sperm preparation techniques. J. Androl. 9: 367-376.

Aitken RJ and West KM (1990). Analysis of the relationship between reactive oxygen species production and leukocyte infiltration in fractions of human semen separated on Percoll gradients. Int. J. Androl. 3: 433-451.

Akiyama M (1999). In vivo scavenging effect of ethylcysteine on reactive oxygen species in human semen. Nihon Hinyokika Gakkai Zasshi 90: 421-428.

Armstrong J, Rajasekaran M, Chamulitrat W, Gatti P, et al. (1999). Characterization of reactive oxygen species induced effects on human spermatozoa movement and energy metabolism. Free Radic. Biol. Med. 26: 869-880.

Askari HA, Check JH, Peymer N and Bollendorf A (1994). Effect of natural antioxidants tocopherol and ascorbic acids in maintenance of sperm activity during freeze-thaw process. Arch. Androl. 33: 11-15.

Ball BA, Medina V, Gravance CG and Baumbe I (2001). Effect of antioxidants on preservation of motility, viability and acrosomal integrity of equine spermatozoa during storage at $5^{\circ} \mathrm{C}$. Theriogenology $56: 577-589$.

Beconi MT, Francia CR, Mora NG and Affranchino MA (1993). Effect of natural antioxidants on frozen bovine semen preservation. Theriogenology 40: 841-851.

Branco CS, Garcez ME, Pasqualotto FF, Erdtman B, et al. (2010). Resveratrol and ascorbic acid prevent DNA damage induced by cryopreservation in human semen. Cryobiology 60: 235-237.

Chew BP (1995). Antioxidant vitamins affect food animal immunity and health. J. Nutr. 125: 1804S-1808S.

Dawson EB, Harris WA, Teter MC and Powell LC (1992). Effect of ascorbic acid supplementation on the sperm quality of smokers. Fertil. Steril. 58: 1034-1039.

De Lamirande E, Jiang H, Zini A, Kodama H, et al. (1997). Reactive oxygen species and sperm physiology. Rev. Reprod. 2: $48-54$.

Flohé L and Otting F (1984). Superoxide dismutase assays. Methods Enzymol. 195: 93-104.

Foote RH, Brockett CC and Kaproth MT (2002). Motility and fertility of bull sperm in whole milk extender containing antioxidants. Anim. Reprod. Sci. 71: 13-23.

Fraga CG, Motchnik PA, Shigenaga MK, Helbock HJ, et al. (1991). Ascorbic acid protects against endogenous oxidative DNA damage in human sperm. Proc. Natl. Acad. Sci. U. S. A. 88: 11003-11006.

Ghosh D, Das UB and Misro M (2002). Protective role of alpha-tochopherol-succinate (provitamin-E) in cyclophosphamide induced testicular gametogenic steroidogenic disorders: a correlative approach to oxidative stress. Free Radic. Res. 36: $1209-1218$.

Góth L (1991). A simple method for determination of serum catalase activity and revision of reference range. Clin. Chim. Acta 196: 143-151.

Hu JH, Tian WQ, Zhao XL, Zan LS, et al. (2010). The cryoprotective effects of ascorbic acid supplementation on bovine semen quality. Anim. Reprod. Sci. 121: 72-77.

Hughes CM, Lewis SE, McKelvey-Martin VJ and Thompson W (1998). The effects of antioxidant supplementation during Percoll preparation on human sperm DNA integrity. Hum. Reprod. 13: 1240-1247.

Huszar G and Vigue L (1994). Correlation between the rate of lipid peroxidation and cellular maturity as measured by creatine kinase activity in human spermatozoa. J. Androl. 15: 71-77.

Iwasaki A and Gagnon C (1992). Formation of reactive oxygen species in spermatozoa of infertile patients. Fertil. Steril. 57: 409-416.

Jones R and Mann T (1977). Damage to ram spermatozoa by peroxidation of endogenous phospholipids. J. Reprod. Fertil. 50: 261-268.

Li Z, Lin Q, Liu R, Xiao W, et al. (2010). Protective effects of ascorbate and catalase on human spermatozoa during cryopreservation. J. Androl. 31: 437-444.

Maia Mda S, Bicudo SD, Sicherle CC, Rodello L, et al. (2010). Lipid peroxidation and generation of hydrogen peroxide in frozen-thawed ram semen cryopreserved in extenders with antioxidants. Anim. Reprod. Sci. 122: 118-123.

Marchlewicz M, Wiszniewska B, Gonet B, Baranowska-Bosiacka I, et al. (2007). Increased lipid peroxidation and ascorbic acid utilization in testes and epididymis of rats chronically exposed to lead. Biometals 20: 13-19.

Marti E, Mara L, Marti JI, Muiño-Blanco T, et al. (2007). Seasonal variations in antioxidant enzyme activity in ram seminal plasma. Theriogenology 67: 1446-1454.

Massaeli H, Sobrattee S and Pierce GN (1999). The importance of lipid solubility in antioxidants and free radical generating systems for determining lipoprotein peroxidation. Free Radic. Biol. Med. 26: 1524-1530.

Genetics and Molecular Research 14 (1): 2572-2581 (2015)

CFUNPEC-RP www.funpecrp.com.br 
O'Flaherty C, Beconi M and Beorlegui N (1997). Effect of natural antioxidants, superoxide dismutase and hydrogen peroxide on capacitation of frozen-thawed bull spermatozoa. Andrologia 29: 269-275.

Pasqualotto FF, Sharma RK, Kobayashi H, Nelson DR, et al. (2001). Oxidative stress in normospermic men undergoing infertility evaluation. J. Androl. 22: 316-322.

Paudel K, Kumar S, Meur S and Kumaresan A (2010). Ascorbic acid, catalase and chlorpromazine reduce cryopreservationinduced damages to crossbred bull spermatozoaa. Reprod. Domest. Anim. 45: 256-262.

Richardson DW (1976). Proceedings: The results of artificial insemination with frozen semen. Br. J. Obstet. Gynaecol. 83: 411.

Sharma R and Agarwal A (1996). Role of reactive oxygen species in male infertility. Urology 48: 835-850.

Sönmez M and Demirci E (2004). The effect of ascorbic acid on the freezability of ram semen diluted with extenders containing different proportions of glycerol. Turk. J. Vet. Anim. Sci. 28: 893-899.

Stradaioli G, Noro T, Sylla L and Monaci M (2007). Decrease in glutathione (GSH) content in bovine sperm after cryopreservation: comparison between two extenders. Theriogenology 67: 1249-1255.

Thérond P, Auger J, Legrand A and Jouannet P (1996). Alpha-tocopherol in human spermatozoa and seminal plasma: relationships with motility, antioxidant enzymes and leukocytes. Mol. Hum. Reprod. 2: 739-744.

Upreti GC, Jensen K, Munday R, Duganzich DM, et al. (1998). Studies on aromatic amino acid oxidase activity in ram spermatozoa: role of pyruvate as an antioxidant. Anim. Reprod. Sci. 51: 275-287.

Zhang Z (2004). Reproduction of domestic animals. China Agriculture Press, Beijing.

Zhao X and Wang G (1999). The Study on Keeping Sperm Trial in Boer Goats. Prog. Vet. Med. 20: 31-33. 